\title{
Upper Jurassic (Lower Kimmeridgian-Olvido) carbonate strata from the La Popa Basin diapirs, NE Mexico
}

\author{
Francisco J. Vega ${ }^{1, *}$, Timothy F. Lawton ${ }^{2}$ \\ ${ }^{1}$ Instituto de Geología, Universidad Nacional Autónoma de México. Ciudad Universitaria, 04510 Coyoacán, \\ México, D. F. \\ ${ }^{2}$ Institute of Tectonic Studies, New Mexico State University. Las Cruces, New Mexico 88003, United States of \\ America \\ *vegver@unam.mx
}

\begin{abstract}
Carbonate strata that occur as blocks encased in gypsum of three different salt diapirs in La Popa Basin contain a single invertebrate fauna indicating a Late Jurassic (Kimmeridgian) age for all sampled fossiliferous blocks. The most biostratigraphically significant species, present in all diapirs, is the gryphaeid oyster Nanogyra virgula. Other species identified in the blocks include the bivalves Astarte gracilicostula, Cercomya durangensis, Myophorella sp., Grammatodon sp. and the nautiloid Cymatoceras? sp. Geologic relations of the entire assemblage of carbonate blocks, including nodular gypsum interbedded with the fossiliferous beds, salt casts in micrite of the blocks, random structural position of blocks within the diapiric evaporite, absence of blocks younger than Early Kimmeridgian in the diapirs, and regional stratigraphic relations, suggest that the carbonate strata were originally interbedded with, or directly overlie, evaporite strata. This inference is corroborated by the presence of Nanogyra virgula (previously reported as Exogyra cf. E. susplicifera) in carbonate strata directly overlying massive gypsum at Potrero Minas Viejas, adjacent to La Popa Basin. Although previously correlated with the Zuloaga Limestone, the fauna in the carbonate blocks of the diapir instead indicate a correlation with carbonate and evaporite strata of the Olvido Formation, and by extension, with siliciclastic strata of La Caja and La Casita formations. The new biostratigraphic data thus indicate that evaporite deposition persisted into the Kimmeridgian and, because the fossiliferous beds are inferred to have overlain a very thick section of halite $(>2 \mathrm{~km})$, it is suggested that evaporite deposition was continuous with only brief interludes of carbonate deposition from Callovian to early Kimmeridgian time in La Popa Basin.
\end{abstract}

Keywords: Late Jurassic, bivalves, evaporites, La Popa Basin, NE Mexico

\section{Resumen}

Los estratos de carbonato que se encuentran como bloques incluidos en yeso de los tres diferentes diapiros en la Cuenca de La Popa, contienen una sola fauna de invertebrados que indica una edad correspondiente al Jurásico Tardio (Kimeridgiano) para todos los bloques muestreados. La especie bioestratigráficamente más significativa, presente en todos los diapiros, es el ostreoideo griféido Nanogyra virgula. Otras especies identificadas de los bloques incluyen los bivalvos Astarte gracilicostula, Cercomya durangensis, Myophorella sp., Grammatodon sp. y el nautiloideo Cymatoceras? sp. Las relaciones geológicas de la totalidad de los bloques, incluyendo yeso nodular interestratificado con las capas fosiliferas, moldes de sal en micrita de los bloques, la posición estructural aleatoria dentro de la evaporita dipírica, la ausencia de bloques más jóvenes que el Kimeridgiano y la estratigrafía regional, sugieren que los estratos de carbonato estaban originalmente interestratificados con, o directamente sobre, los estratos de evaporitas. Esta interpretación se refuerza con la presencia de Nanogyra virgula (reportada anteriormente como Exogyra cf. E. susplicifera) en estratos de carbonato que yacen directamente sobre yeso masivo en el Potrero Minas Viejas, adyacente a la Cuenca de La Popa. Los estratos de carbonato de los bloques fueron previamente correlacionados con la Caliza Zuloaga; sin embargo, la fauna indica una correlación con estratos de carbonato y evaporita de la Formación Olvido, así como con los estratos siliciclásticos de las formaciones La Caja y La 
Casita. Hasta ahora, los nuevos datos bioestratigráficos indican que la deposición de las evaporitas persistió hasta el Kimeridgiano. Dado que se infiere que las capas fosiliferas yacen sobre una sección de halita muy gruesa $(>2 \mathrm{~km})$, se sugiere que la deposición de las evaporitas fue continua, con interrupciones breves, desde el Caloviano hasta el Kimeridgiano Temprano en la Cuenca de la Popa.

Palabras clave: Jurásico Tardio, bivalvos, evaporitas, Cuenca de La Popa, NE de México

\section{Introduction}

In this paper we describe oysters and other invertebrate fossils present in blocks of carbonate strata encased in diapiric evaporite in three diapirs in La Popa Basin, north of Monterrey, in the state of Nuevo León, Mexico (Figure 1). The fossils indicate that the carbonate strata in each of these diapirs are of early Late Jurassic age and place constraints on the minimum depositional age of the evaporite.

In spite of its importance to reconstructions of the Gulf of Mexico and Pangea, the Jurassic stratigraphy of northeastern Mexico remains debated due to a paucity of fossil material from evaporite and carbonate strata that record the initial incursion of marine conditions into the region west of the Tamaulipas arch. The Tamaulipas arch is a basement block that separates basins of northeastern Mexico from the Gulf of Mexico Basin (Wilson, 1990; Eguiluz de Antuñano, 2001). The Jurassic section of the Sierra Madre and its foreland has been variously argued to contain one evaporite succession of Middle to early Late Jurassic age, termed the Minas Viejas Formation (Götte and Michalzik, 1992; Kroeger and Stinnesbeck, 2003) overlain by the Zuloaga Formation, or two evaporite successions, the Minas Viejas Formation and younger Olvido Formation, of Kimmeridgian age, separated by the Zuloaga Formation, a marine limestone (e. g.,Goldhammer, 1999; Oivanki, 1974; Salvador, 1987; Goldhammer, 1999). The age of the Zuloaga itself is poorly constrained because it generally lacks fossils with biostratigraphic significance. Improved ages on the evaporite and carbonate strata have the potential to improve correlation of strata between northeastern Mexico and the Gulf of Mexico Basin, advance understanding of sequence stratigraphy in the region, and better focus paleogeographic reconstructions of the entire region. The biostratigraphic data presented here are thus of significant importance to the geology and tectonics of northeastern Mexico.

\section{Geologic setting}

Strata exposed in La Popa Basin range in age from Early Cretaceous to Eocene, but salt diapirs in the basin contain older evaporite and provide geologic insight into the pre-Cretaceous stratigraphy of the basin. Diapirs in the main part of the basin are termed El Papalote and El Gordo (Figure 1: McBride et al., 1974; Laudon, 1984; Lawton et al., 2001). A newly described diapir at Cerro La Paz lies on the southern edge of La Popa Basin (Figure 1; Holbrook, 2008).

Blocks of stratigraphically coherent carbonate are present in the diapirs. El Papalote and El Gordo diapirs contain carbonate and mafic igneous blocks of many sizes, with large carbonate blocks having elliptical shapes that attain dimensions of 100 by $200 \mathrm{~m}$ (Garrison and McMillan, 1999; Figures 2 and 3). Beds in the blocks at El Papalote diapir are 15 to $30 \mathrm{~cm}$ thick, generally composed of dark gray micrite interbedded with thin partings of shale and poorly exposed gypsum. The fossiliferous bed in the sampled block at El Papalote is $30 \mathrm{~cm}$ thick, forms a prominent ridge that is nearly continuous around the perimeter of the block, and contains numerous fossils in gray micrite. Other blocks consist of black medium-crystalline dolostone in beds $15 \mathrm{~cm}$ to $1 \mathrm{~m}$ thick. The carbonate strata in the elliptical blocks dip inward and have saucer-like forms. Elsewhere, carbonate strata in other blocks dip steeply to vertically. Blocks of carbonate strata at the Cerro La Paz diapir are uncommon and have smaller dimensions. The fossils described here, from that diapir, were collected from a block of carbonate strata in an exploration roadcut (Figure 4). Block dimensions are no more than $3 \mathrm{~m}$ thick by $20 \mathrm{~m}$ long. These blocks are no longer in their original stratigraphic position, but have been transported as much as $3000 \mathrm{~m}$ above their original depositional site by salt movement; because much salt has been removed by erosion from these diapirs during erosion of the Paleogene part of the stratigraphic section in La Popa Basin, it is unlikely that the blocks are juxtaposed with their original evaporite stratigraphy (e.g., Rowan et al., 2003). Nevertheless, nodular gypsum and micrite interbedded with carbonate strata resembling the blocks sampled here are exposed in a quarry in El Papalote diapir (Figure 5), indicating that carbonate and evaporite strata were interbedded prior to diapiric transport (Lawton et al., 2001).

Carbonate strata in the diapiric blocks have long been known to contain Late Jurassic fossils. Exogyra sp. cf. E. virgula was reported from the large elliptical block in the northeastern corner of El Papalote diapir and interpreted as Kimmeridgian (Laudon, 1984). The fossils of the same block in El Papalote and one in El Gordo diapir were later reexamined and determined to include Nanogyra striata (Smith), a Kimmeridgian oyster (Lawton et al., 2001). Lawton et al. (2001) also reported Oxfordian fossils from the same stratigraphic interval in the block of El Papalote 


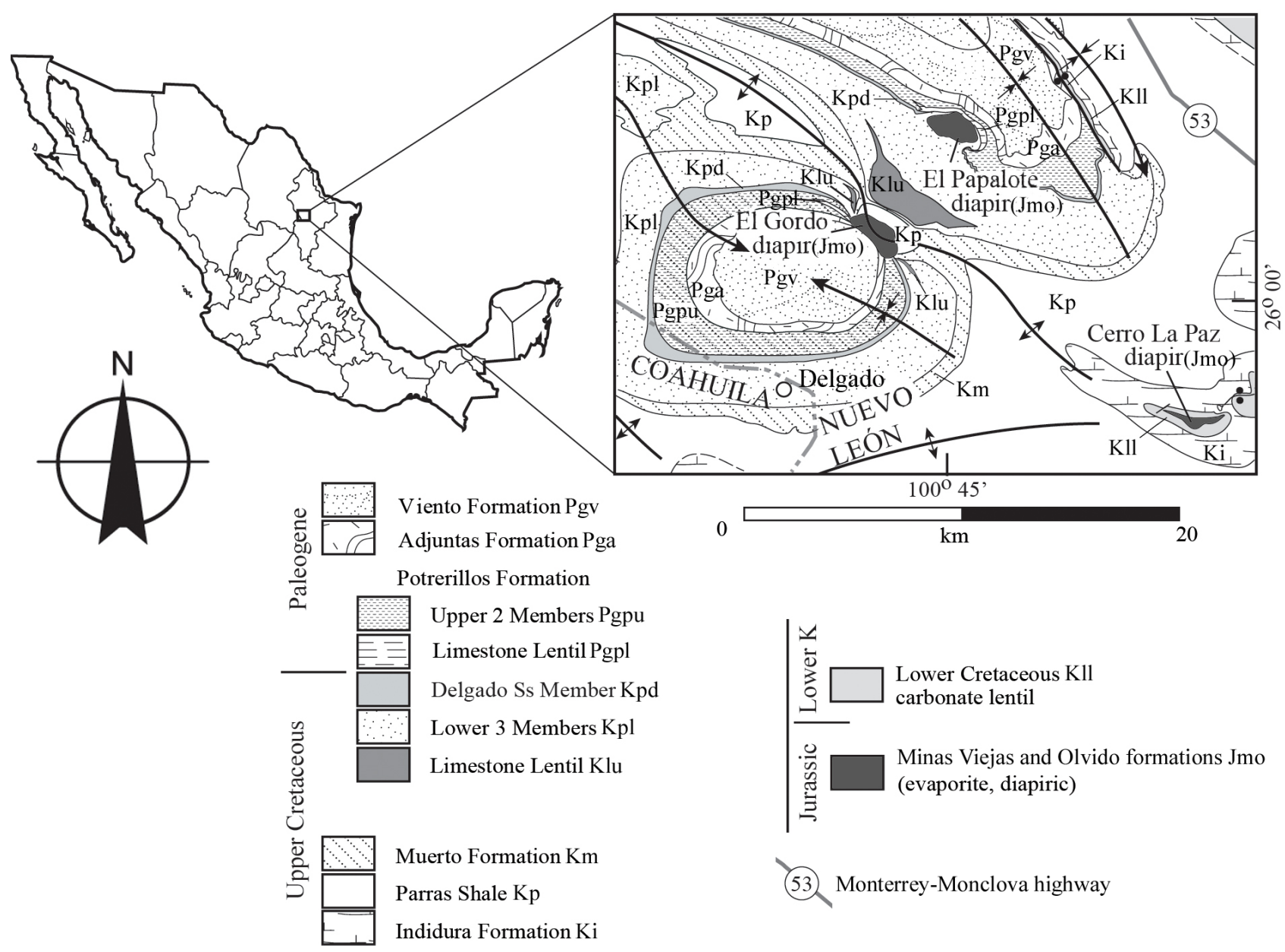

Figure 1. Location map of La Popa Basin, NE Mexico, indicating El Papalote, El Gordo and Cerro La Paz diapirs.

diapir, indicating the possibility that the carbonate rocks included strata older than Kimmeridgian. Blocks younger than the Kimmeridgian strata described here (e. g., Lower Cretaceous through Paleogene strata) are unknown in any of the diapirs, indicating that neither strata younger than the evaporite nor diapiric wall rocks were entrained in the evaporite (Lawton et al., 2001; Rowan et al., 2003).

\section{Paleontology}

Laudon (1984) and Lawton et al. (2001) offered preliminary identifications for molluscan species found in Jurassic blocks of El Papalote and El Gordo diapirs of La Popa Basin. A more detailed review of those species is presented here, with interpretations on the paleoenvironment and biostratigraphy.

Several specimens of mollusks were collected from blocks present in three diapirs in La Popa Basin. The most representative species, present in all three diapirs, is the gryphaeid oyster Nanogyra virgula (Defrance, 1821) which is usually found in fine-grained siliciclastic and carbonate sediments, and lived reclining on the substrate by means of a concave left valve in what has been called the "iceberg" strategy (Thayer, 1975; Jablonski and Bottjer, 1983). The oysters are commonly unabraded and articulated in banks at El Papalote diapir (Figures 6.10 to 6.13, and 6.19 to 6.22 ), scarce and weathered, but still articulated at El Gordo diapir (Figures 6.14 to 6.17), and very scarce, weathered and disarticulated at the Cerro La Paz diapir (Figures 6.18 and 6.23). The patterns of abundance and disarticulation suggest transport, probably from a series of oyster banks similar to the ones present in blocks at El Papalote diapir. Oyster-bearing strata are present in the elliptically-shaped block in the NE edge of El Papalote diapir. At this location the oysters are apparently in situ and experienced little or no subsequent transport, as valves are still articulated and there are diverse sizes, representing different stages of development. Fürsich and Oschmann (1986a) interpreted coquinoid deposits of Nanogyra virgula from the Upper Jurassic of France as storm deposits, based on occurrence of disarticulated and fragmentary valves. The oyster banks at El Papalote are interpreted to have developed under shallow marine conditions in a sabkha environment, with tidal influence that provided periodic input of organic matter and normal marine water. 


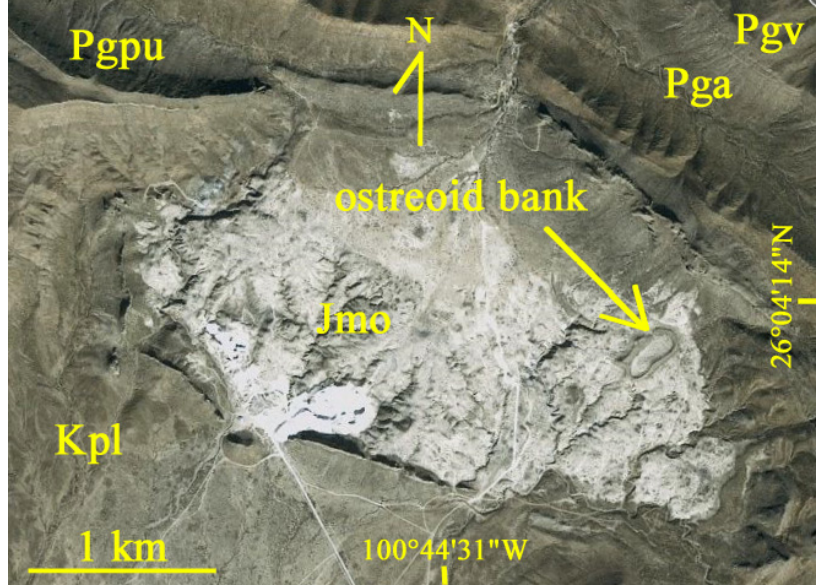

Figure 2. Detail of El Papalote diapir with location of block with Nanogyra virgula banks. Key: Jmo = Callovian(?)-Kimmeridgian evaporites equivalent to Minas Viejas and Olvido formations; $\mathrm{Kpl}=$ Maastrichtian lower Potrerillos Formation; Pga = Eocene Adjuntas Formation; Pgpu = Paleocene upper Potrerillos Formation; Pgv $=$ Eocene Viento Formation

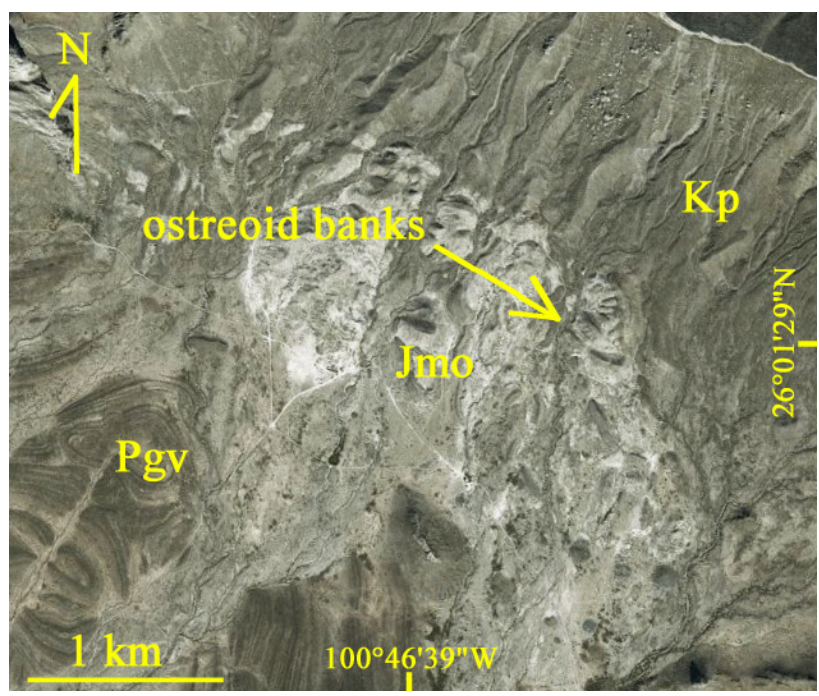

Figure 3. Detail of El Gordo diapir with location of blocks with Nanogyra virgula . Key $\mathrm{Jmo}=$ Callovian(?)-Kimmeridgian evaporites equivalent to Minas Viejas and Olvido formations; Kp = Campanian Parras Shale; Pgv $=$ Eocene Viento Formation.

The ostreoid species was reported as Nanogyra striata (synonym of $N$. virgula) from the Kimmeridgian La Caja Formation by Buitrón (1984), as well as from other Jurassic localities of NE Mexico and SW United States (Burckhardt, 1930; Imlay, 1945). Humphrey and Diaz (1956; page 38 in Humphrey and Diaz, 2003) reported the presence of small specimens of Exogyra cf. E. susplicifera (Felix, 1891) in the basal Zuloaga Limestone at Sierra Minas Viejas). E. susplicifera was originally described by Felix (1891) for the Upper Jurassic of Tlaxiaco, Oaxaca. A closer examination to the description and illustrations ( $\mathrm{p}$. 177, lam. 27, Figures 6 and 7 in Felix, 1891; p. 324, Figure $122 \mathrm{c}$ in Carreño et al., 1989) suggests that this species should be considered synonymous with Nanogyra virgula.

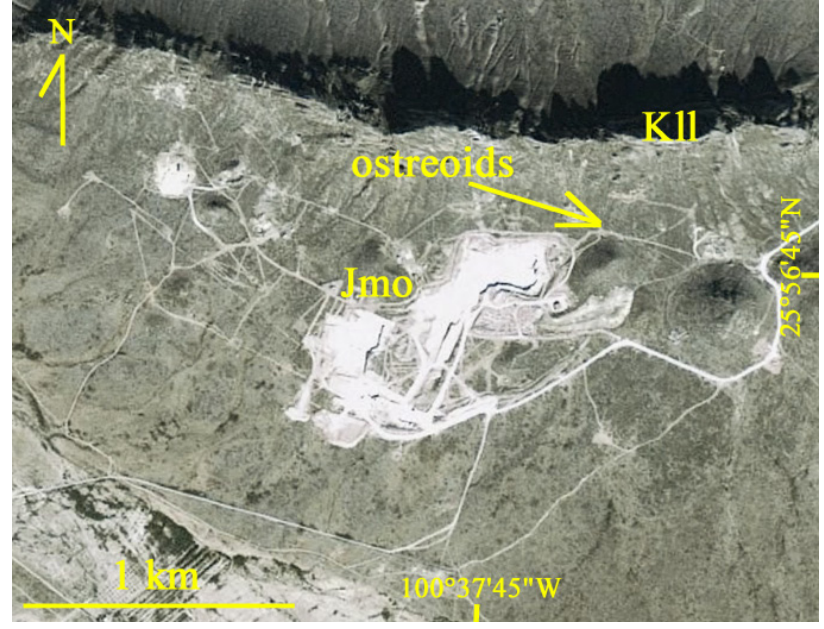

Figure 4. Detail of La Paz diapir with location of block with specimens of Nanogyra virgula. Key: Jmo = Callovian(?)-Kimmeridgian evaporites equivalent to Minas Viejas and Olvido formations; K1l = Lower Cretaceous carbonate lentil.

The small specimens described by Felix (1891) have regularly spaced concentric ridges and very fine radial striae, typical ornamentation of $N$. virgula.

Nanogyra virgula is considered an index fossil for Lower to Middle Kimmeridgian deposits, mainly from Europe (Aubert, 1932; Imlay, 1945; Ziegler, 1969; Pugaczewska, 1971; Cox and Gallois, 1981; Gautret and Hantzpergue, 1982; Fürsich and Oschmann, 1986a; 1986b; Lauxmann, 1991; Machalski, 1998; Jank et al., 2006; Colombié and Rameil, 2007; Scholz et al., 2008). Several specimens of Astarte gracilicostula (Figures 6.5 to 6.7) are present along with Nanogyra virgula banks at El Papalote diapir, and although disarticulated, most specimens still preserve ornamentation, indicating minimal transport. That species was reported from La Casita and La Caja formation outcrops of Coahuila, Zacatecas and Durango (p. 407 in Imlay, 1940), reinforcing a biostratigraphic interpretation for a early to middle Kimmeridgian age for the El Papalote block. Presence of Cercomya durangensis (Figure 6.9) also reinforces this interpretation, as it was reported from La Casita Formation in Durango (p. 410 in Imlay, 1940). A single specimen of Myophorella sp. (Figure 6.4) is articulated but shows deep weathering; species from that genus have been reported from Kimmeridgian beds of Antarctica (Riley et al., 1997), among other localities. Grammatodon sp. (Figure 6.3) is another common bivalve genus in Upper Jurassic outcrops (Surlyk, 1978; Buitrón, 1984; Villaseñor et al., 2005; Meléndez et al., 2006; Delvene et al., 2007). The nautiloid Cymatoceras? sp. (Figure 6.1) was found in the Nanogyra virgula banks of the El Papaote diapir; the genus has been reported from Upper Jurassic and Lower Cretaceous strata (Cichowolski, 2003). Other mollusks found at El Papalote diapir, associated with oyster banks are an indeterminate gastropod, Eocallista? sp. and the bivalve Rastellum sp. (Figures 6.2, 6.8 and 6.24 , respectively). 

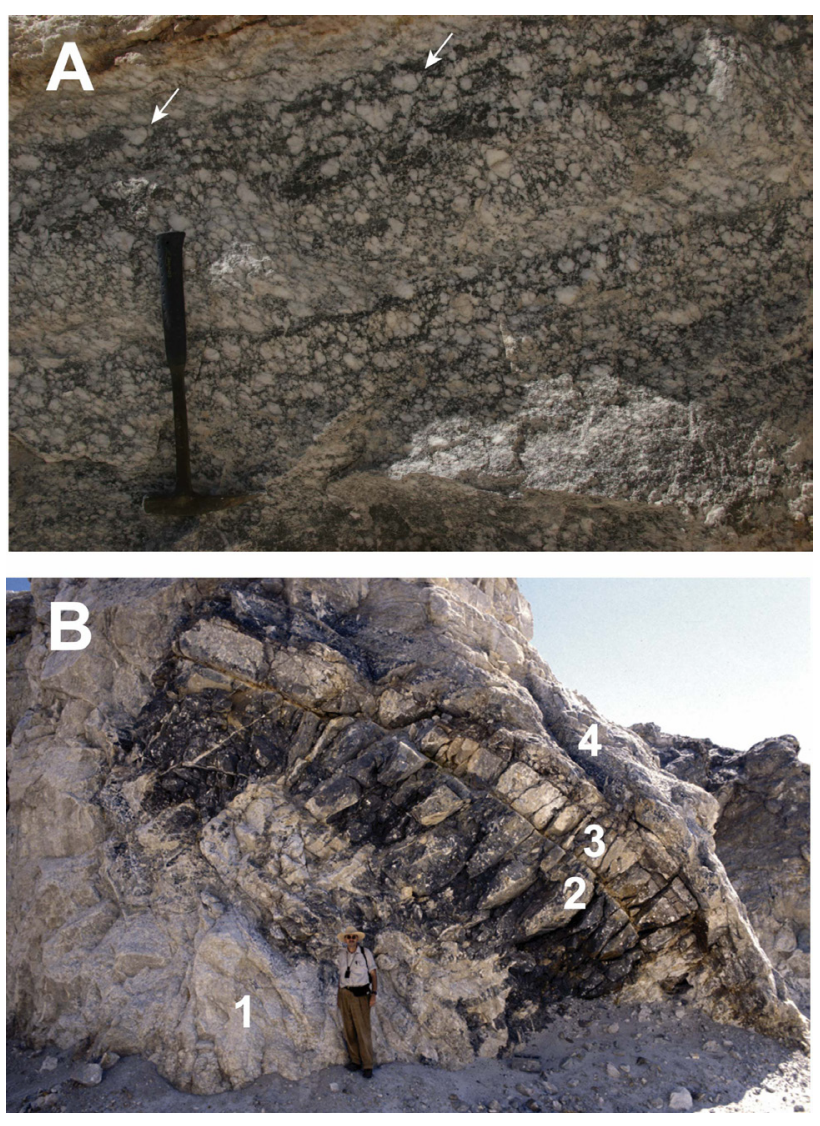

Figure 5. Block of carbonate and evaporite strata exposed in gypsum quarry at El Papalote diapir. (A) Nodular gypsum in dark gray micrite, which defines gently dipping stratification. Arrows indicate wedge-shaped gypsum bodies near top of upper bed, which may indicate recrystallized bladed selenite crystals that formed at sediment-water interface. Hammer is $35 \mathrm{~cm}$ long. (B) Stratified carbonate block. $1=$ Massive coarsely crystalline gypsum of caprock residue; 2 = Dark gray micrite; $3=$ Medium gray micrite with halite casts; $4=$ Nodular, chicken wire gypsum and micrite of 4A.

\section{Discussion}

The paleontological data from the carbonate blocks indicate that despite their somewhat random distribution in three different diapirs in La Popa Basin, many carbonate blocks are early to middle Kimmeridgian in age. This consistent age has important implications for the Jurassic depositional sequence in northeastern Mexico.

Evaporite strata are not directly dated in the Gulf of Mexico Basin or in northeastern Mexico west of the Tamaulipas arch and thus their age is a topic of much debate. The Louann Salt and underlying Werner Anhydrite of the Gulf of Mexico are generally regarded as Callovian (Salvador, 1987). This age is inferred on the basis of bracketing ages of underlying and overlying strata, although the bracket is imprecise. Underlying Eagle Mills red beds are generally regarded as Lower Jurassic, and the oldest biostratigraphically significant fossils above the salt are from the lower part of the Smackover Formation, which contains late Oxfordian ammonites (Figure 7; Salvador,
1987). Redbeds of the Huizachal Group in the Sierra Madre Oriental, which underlie evaporite strata and have long been considered Middle Jurassic (Salvador, 1987), have recently yielded maximum depositional ages near the Bathonian-Callovian boundary ( $165 \mathrm{Ma})$ from detrital zircon U-Pb ages (Rubio-Cisneros and Lawton, 2011), indicating that the evaporites of the Sierra Madre can be no older than Callovian. Pindell and Kennan (2007) inferred that salt deposition ended in the Gulf of Mexico in the early to middle Oxfordian ( $c a .158 \mathrm{Ma}$ ) on the basis of plate reconstructions for the opening of the Gulf. Blocks of lamprophyre, which have geochemical characteristics consistent with derivation from mantle melts, recovered from Louisiana salt domes, recently yielded early to middle Oxfordian (161-159 Ma) ${ }^{40} \mathrm{Ar} /{ }^{39} \mathrm{Ar}$ cooling ages (Stern et al., 2010). These ages are compatible with formation of oceanic crust in the Gulf of Mexico immediately prior to or during salt deposition (e. g., Pindell and Kennan, 2007) and thus corroborate the inference of salt deposition into the Oxfordian. Thus, the current bracketed age range of salt in the Gulf of Mexico and northeastern Mexico can be regarded as Callovian to Early Oxfordian (Figure 7).

The carbonate strata in the blocks at El Papalote diapir have previously been correlated with the Zuloaga Limestone of northeastern Mexico (Laudon, 1984; Lawton et al., 2001), which is generally considered Oxfordian on the basis of its stratigraphic position beneath Kimmeridgian strata of the La Casita Formation (Humphrey and Diaz, 1956; Oivanki, 1974; Salvador, 1987; Goldhammer, 1999). The Zuloaga Limestone lacks biostratigraphically diagnostic fossils throughout its region of distribution, but it is overlain by the correlative Kimmeridgian La Casita and La Caja formations. Near the village of Galeana, in the Sierra Madre Oriental south of Monterrey, there is an interval of Kimmeridgian limestone, gypsum and shale termed the Olvido Formation that overlies the Zuloaga Limestone and underlies the La Caja Formation (Heim, 1940; Humphrey and Diaz, 1956; Oivanki, 1974; Salvador, 1987). The nearest exposure to the diapirs of carbonate strata assigned to the Zuloaga is in Potrero Minas Viejas, about $15 \mathrm{~km}$ from the southeastern corner of La Popa Basin. There, the carbonate strata overlie evaporites assigned to the Minas Viejas Formation on the crest of a detachment fold (Humphrey, 1956; Humphrey and Diaz, 1956; Oivanki, 1974; LópezRamos, 1982; Goldhammer, 1999). Goldhammer (1999) regarded the evaporite as Callovian(?) and interpreted this contact as a significant unconformity or sequence boundary related to post-rift continental breakup in the Gulf of Mexico. In contrast, Salvador (1987; p. 434) argued pointedly that the evaporites at Potrero Minas Viejas and in the Sierra El Fraile are younger than the salt of the Louann Formation: "Near Monterrey the lower anhydrite and salt unit of the Olvido Formation has been called "Minas Viejas" and mistakenly correlated with the older WernerLouann evaporite section..." In fact, Humphrey and Diaz (1956; p. 38) noted the presence of Exogyra cf. E. susplici- 

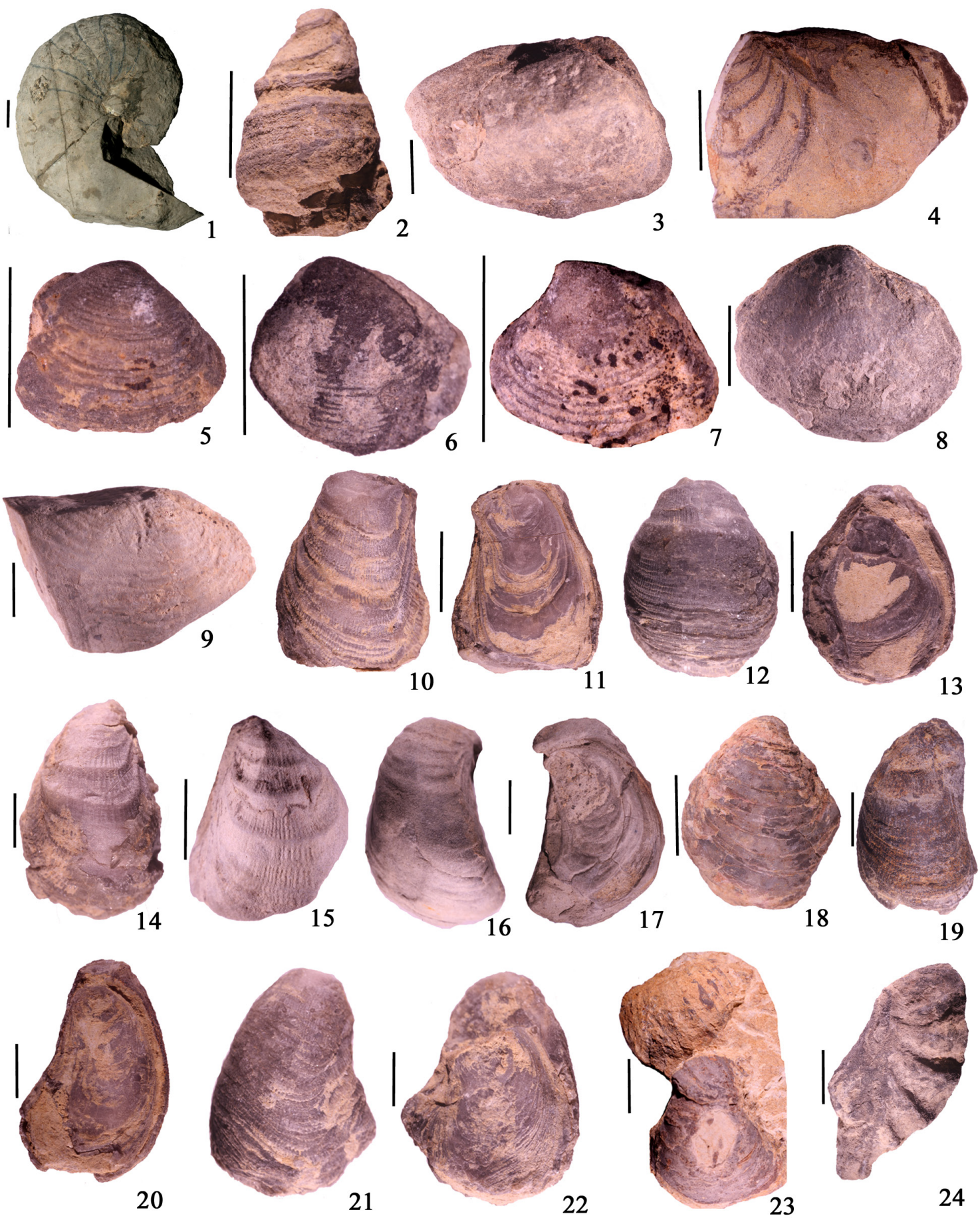

24

Figure 6. (1). Cymatoceras? sp., El Papalote diapir, hypotype IGM6245, X0.5. (2) Indeterminate gastropod, El Papalote diapir, hypotype IGM6246, X3.0. (3) Grammatodon sp. El Papalote diapir, hypotype IGM6247, X1.5. (4) Myophorella sp., right valve, El Papalote diapir, hypotype IGM6248, X2.0. (5 to 7) Astarte gracilicostula Imlay, 1940. El Papalote diapir, hypotypes IGM6249 to IGM6251, all specimens X6.0: (5 and 6) Right valve; (7) Left valve. (8) Eocallista sp., right valve, El Papalote diapir, hypotype IGM6252, X1.5. (9) Cercomya durangensis Imlay, 1940, left valve, El Papalote diapir, hypotype IGM6705, X1.5. (10 to 23) Nanogyra virgula (Defrance, 1821). (10 and 11) Left and right valves, respectively, El Papalote diapir, hypotype IGM6706, X2.5; (12 and 13) Left and right valves, respectively, El Papalote diapir, hypotype IGM6707, X2.5; (14) Left valve, El Papalote diapir, hypotype IGM6708, X3.0; (15) Left valve, El Gordo diapir, hypotype IGM6709, X3.0; (16 and 17) Left and right valves, respectively, El Gordo diapir, hypotype IGM6710, X1.5; (18) Left valve, La Paz diapir, hypotype IGM6711, X12.0; (19 and 20) Left and right valves, respectively, El Papalote diapir, hypotype IGM6712, X2.0; (21 and 22) Left and right valves, respectively, El Papalote diapir, hypotype IGM6713, X2.5; (23) Left valves, La Paz diapir, hypotype IGM6714, X0.5. (24) Rastellum sp., left valve, El Papalote diapir, hypotype IGM6715, X1.5. 


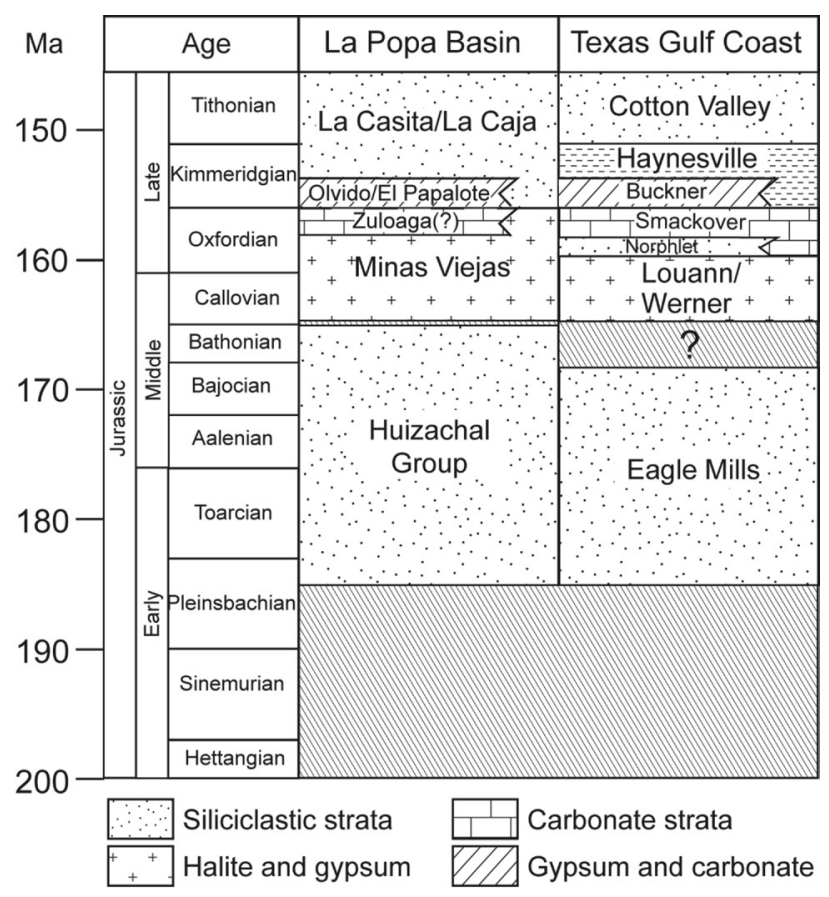

Figure 7. Stratigraphic correlation of Jurassic formations in and adjacent to La Popa Basin with formations of the northern Gulf of Mexico. Huizachal Group strata are inferred to be present at depth in the basin from relations in the Sierra Madre Oriental. "El Papalote" is informal designation for carbonate strata in diapirs correlative with Olvido Formation of Sierra Madre Oriental, used here to highlight equivalence to Olvido and location in diapiric evaporite of La Popa Basin. Interval identified as Zuloaga-Olvido?-El Papalote is disrupted by evaporite movement in diapirs, but inferred to represent carbonate strata that overlie evaporite strata in Potrero Minas Viejas. Presence of Zuloaga unconfirmed in La Popa Basin and previously identified Zuloaga better considered Olvido in Potrero Minas Viejas, directly southeast of La Popa Basin. See text for explanation.

fera (which as previously mentioned, should be considered synonymous with Nanogyra virgula) in the lower $35 \mathrm{~m}$ of carbonate and shale strata overlying the gypsum.

Although the original stratigraphic thickness of the evaporite section subjacent to the carbonate strata at Potrero Minas Viejas and in La Popa Basin is unknown, structural evidence suggests that it was originally very thick, perhaps in excess of $2 \mathrm{~km}$. The Minas Viejas \#1 exploration well, drilled on the crest of the anticline at Potrero Minas Viejas, encountered $600 \mathrm{~m}$ of gypsum, $900 \mathrm{~m}$ of interbedded gypsum and halite, $2100 \mathrm{~m}$ of halite, several meters of basalt or gabbro, $520 \mathrm{~m}$ of interbedded black carbonaceous limestone and halite, and a basal interval consisting of $370 \mathrm{~m}$ of black carbonaceous limestone (López-Ramos, 1982). The changing lithologies with depth, although almost certainly structurally thickened or steeply dipping, can be interpreted as a stratigraphic section recording the development of a salt basin that with time became increasingly influenced by open marine conditions, evolving from halite deposition, through gypsum and halite, and ultimately to gypsum and carbonate deposition (Lawton et al., 2001). Although much of the salt has been evacuated from La Popa Basin by diapirism, the deeper basement beneath the basin relative to high-standing basement of the neighboring Tamaulipas arch could have accommodated a minimum of $1.5 \mathrm{~km}$ of salt that has since been removed by diapirism (Lawton et al., 2001).

The carbonate strata in Potrero Minas Viejas and two nearby detachment folds at Potreros Chico and Garcia are overlain by shale of the Kimmeridgian La Casita Formation (Humphrey, 1956; Humphrey and Diaz, 1956; Oivanki, 1974; López-Ramos, 1982); therefore, the distinction between Zuloaga and Olvido is evidently not present at the type locality of the Minas Viejas Formation. Arguing that the terms Olvido and Zuloaga are synonymous, Götte and Michalzik (1992) and Kroeger and Stinnesbeck (2003) inferred that interbedded gypsum and carbonate strata near Galeana in the Sierra Madre Oriental are better termed Minas Viejas than Olvido, argued for a Kimmeridgian age on the basis of stratigraphic proximity to the overlying La Casita Formation and recommended abandonment of the term Olvido. Nevertheless, there are no direct biostratigraphic ages in support of the young age for the evaporitecarbonate succession near Galeana.

The proximity of the strata at Potrero Minas Viejas to the diapirs of La Popa Basin, the general similarity of the carbonate rock types at the four localities, and the discovery that Nanogyra virgula is indeed present at Potrero Minas Viejas indicate the likelihood that the evaporite and carbonate strata at all localities are correlative. The combined stratigraphic relations suggest that halite deposition at all localities was succeeded by deposition of interbedded gypsum and halite, and finally deposition of interbedded gypsum and carbonate of Kimmeridgian age, or perhaps only carbonate and shale at Potrero Minas Viejas. In this stratigraphic model (Figure 7), the Kimmeridgian carbonate and evaporite strata at El Papalote diapir correlate with the Olvido Formation and thus represent the younger episode of evaporite deposition in the region, as inferred by Salvador (1987) and Goldhammer (1999). The evident correlation of the carbonate strata in the diapirs with the beds assigned to the Zuloaga at Potrero Minas Viejas indicates that either Oxfordian strata of the Zuloaga are not present in the Potrero or that the Zuloaga is largely early Kimmeridgian. Nevertheless, the potential presence of several $\mathrm{km}$ of halite stratigraphically beneath the gypsum and carbonate indicates the likelihood that older Callovian-Oxfordian evaporite equivalent to the Louann Salt is present in and adjacent to La Popa Basin.

The apparent absence of Oxfordian carbonate in $\mathrm{La}$ Popa Basin and possibly at Potrero Minas Viejas is an unresolved stratigraphic problem. The missing Oxfordian may result from: (1) our failure to find and date true Oxfordian Zuloaga Limestone, a strong possibility given the presence of unfossiliferous carbonate blocks in the diapirs and the paucity of fossils in the Zuloaga Limestone of the region (e. g., Oivanki, 1974; this possibility is illustrated 
by inclusion of Zuloaga Limestone in the stratigraphic column of Figure 7); (2) the likelihood that the carbonate strata previously identified as Zuloaga Limestone at Potrero Minas Viejas are in fact Kimmeridgian and better regarded as Olvido Formation (e. g., Salvador, 1987); or (3) the possibility that Oxfordian (Zuloaga) carbonate strata were not deposited in La Popa salt basin because geographic restriction of the basin promoted continued deposition of evaporite. Indeed, the bank-like paleoecology of the carbonate strata implies that El Papalote diapir was already a topographic, perhaps diapiric, feature in the Kimmeridgian to permit oyster bank development during marine transgressions into the salt basin. A final possibility is that the Oxfordian fossils reported from El Papalote diapir (Lawton et al., 2001) indicate the presence of thin Zuloaga there. Only further work on the carbonate strata at Potrero Minas Viejas can resolve these alternative possibilities.

An unequivocal Kimmeridgian age for carbonate strata in the diapirs has important implications for the age range of salt in northeastern Mexico. The biostratigraphic data presented here and stratigraphic relations observed in the blocks indicate that evaporite deposition continued into the Kimmeridgian in La Popa Basin and probably also at neighboring Potrero Minas Viejas. This upper age limit suggests that evaporite deposition took place from Callovian through early Kimmeridgian time in northeastern Mexico, an age range similar to that spanned by the entire LouannBuckner evaporite interval of the Gulf of Mexico (Figure 7). Evaporite deposition was thus terminated in La Popa Basin by major marine transgression in early Kimmeridgian time.

\section{Conclusions}

Blocks of carbonate strata in three diapirs of La Popa salt basin all contain the gryphaeid oyster Nanogyra virgula (Defrance, 1821) of Kimmeridgian age. Shell preservation and articulation suggest that the oysters were distributed southward from tidal banks located in the central part of the present basin. The carbonate strata of the diapirs thus correlate with the Olvido Formation of the Sierra Madre Oriental. The inferred great original thickness of salt in La Popa Basin nevertheless suggests that stratigraphically deeper halite, penetrated in the subsurface at Potrero Minas Viejas located $15 \mathrm{~km}$ southeast of La Popa Basin, is in part Callovian. Carbonate strata long identified as Zuloaga Limestone that overlie the evaporite section and underlie the Kimmeridgian La Casita Formation at Potrero Minas Viejas correlate with the carbonate strata in the diapirs, but possibly also include Zuloaga-equivalent (Oxfordian) strata. The age-diagnostic fossils and local geologic relations thus indicate that evaporite deposition in and adjacent to La Popa Basin likely spanned Callovian-Early Kimmeridgian time.

\section{Acknowledgments}

M. Cichowolski from the Departamento de Ciencias Geológicas, Universidad de Buenos Aires, offered support for nautiloid identification. Christina Ifrim provided important references. Reviews by Gary Gray and Samuel Eguiluz greatly improved the manuscript.

\section{References}

Aubert, D., 1932, Un niveau à Exogyra virgula, Defrance à la Vallée de Joux: Bulletin de la Société Vaudoise des Sciences Naturelles, 57, $477-478$.

Buitrón, B.E., 1984, Late Jurassic bivalves and gastropods from northern Zacatecas, Mexico, and their paleogeographic significance, in Westermann, G.E.G. (ed.), Jurassic-Cretaceous biochronology and paleogeography of North America: Geological Association of Canada Special Paper, 27, 89-98.

Burckhardt, C., 1930, Étude Synthétique sur le Mesozoique Mexicain: Societé Paleontologique Suisse, Mémoire 49-50, 280 p.

Carreño, A.L., Perrilliat, M.C., González-Arreola, C., Applegate, S.P., Carranza-Castañeda, O., Martínez-Hernández, E., 1989, Fósiles tipo mexicanos: Ciudad de México, Universidad Nacional Autónoma de México, Instituto de Geología, $531 \mathrm{p}$.

Cichowolski, M., 2003, The nautiloid genus Cymatoceras from the Cretaceous of the Neuquén and Austral basins, Argentina: Cretaceous Research, 24, 375-390.

Colombié, C., Rameil, N., 2007, Tethyan-to-boreal correlation in the Kimmeridgian using high-resolution sequence stratigraphy (Vocontian Basin, Swiss Jura, Boulonnais, Dorset): International Journal of Earth Sciences, 96, 567-591.

Cox, B.M, Gallois, R.W., 1981, The stratigraphy of the Kimmeridge Clay of the Dorset type area and its correlation with some other Kimmeridgian sequences: London, Institute of Geological Sciences, Report 80/4, 44 p.

Defrance, A., 1821, Huîtres, Dictionnaire des Sciences naturelles: Paris, F.G. Levrault-Le Normant, 20-33.

Delvene, G., Pérez-Urresti, I., Meléndez, G., 2007, El Jurásico Superior en el sector noroccidental de la Península Ibérica (España): bioestratigrafía y principales grupos de bivalvos: Revista Española de Paleontología, 22, 63-76.

Eguiluz de Antuñano, S., 2001, Geologic evolution and gas resources of the Sabinas basin in northeastern Mexico, in Bartolini, C., Buffler, R.T., Cantú-Chapa, A. (eds.), The western Gulf of Mexico Basin: American Association of Petroleum Geologists, Memoir $75,241-270$.

Felix, J., 1891, Versteinerungen aus der mexicanischen Jura und Kreideformation: Palaeontographica, 37, 140-194.

Fürsich, F.T., Oschmann, W., 1986a, Storm shell beds of Nanogyra virgula in the upper Jurassic of France: Neues Jahrbuch für Geologie und Paläontontologie, Abhandlungen, 172, 141-161.

Fürsich, F.T., Oschmann, W., 1986b, Autecology of the Upper Jurassic oyster Nanogyra virgula (Defrance): Paläontologische Zeitschrift, 60, 65-74

Garrison, J.M., McMillan, N.J., 1999, Evidence for Jurassic continental rift magmatism in northeast Mexico: Allogenic metaigneous blocks in the El Papalote evaporite diapir, La Popa Basin, Nuevo León, Mexico, in Bartolini, C., Wilson, J.L., Lawton, T.F. (eds.), Mesozoic sedimentary and tectonic history of north-central Mexico: Geological Society of America Special Paper, 340, 319-332.

Gautret, P., Hantzpergue, P., 1982, Utilisation biostratigraphique du genre Nanogyra Beurlen dans le Jurassique supérieur nord-Aquitaine (Paléontologie, paleoécologie), in 9e. Réunion annuale des Sciences de La Terre: Paris, Société Géologique de France, 1 p.

Goldhammer, R.K., 1999, Mesozoic sequence stratigraphy and paleogeographic evolution of northeast Mexico, in Bartolini, C., Wilson, J.L., Lawton, T.F. (eds.), Mesozoic sedimentary and tectonic 
history of north-central Mexico: Boulder, Colorado, Geological Society of America Special Paper, 340, 1-58.

Götte, M., Michalzik, D., 1992, Stratigraphic relations and facies sequences of an Upper Jurassic evaporitic ramp in the Sierra Madre Oriental (Mexico): Zentralblatt für Geologie und Palaeontologie, Teil I, 1991, 1445-1466.

Heim, A., 1940, The front ranges of Sierra Madre Oriental, Mexico, from Ciudad Victoria to Tamazunchale: Eclogae Geologicae Helvetiae, 33, 313-362.

Holbrook, C.W., 2008, Geology and stratigraphy of Cerro La Paz and vicinity, La Popa Basin, Mexico: Las Cruces, New Mexico, U. S. A., New Mexico State University, M.S. thesis, 71 p.

Humphrey, W.E., 1956, Tectonic framework of northeast Mexico: Transactions of the Gulf Coast Association of Geological Societies, 6, 25-35.

Humphrey, W.E., Díaz, T., 1956, Jurassic and Lower Cretaceous stratigraphy and tectonics of northeast Mexico, unpublished report, Petróleos Mexicanos, $390 \mathrm{p}$.

Imlay, R.W., 1940, Upper Jurassic pelecypods from Mexico: Journal of Paleontology, 14, 393-411.

Imlay, R.W., 1945, Jurassic fossils from the southern states, No. 2: Journal of Paleontology, 19, 253-276.

Jablonski, D., Bottjer, D.J., 1983, Soft-bottom epifaunal suspensionfeeding assemblages in the Late Cretaceous: Implications for the evolution of benthic paleocommunities, in Tevesz, M.J.S., McCall, P.L. (eds.), Biotic Interactions in Recent and Fossil Benthic Communities: New York, Plenum, 747-812.

Jank, M., Meyer, C.A., Wetzel, A., 2006 Press, Late Oxfordian to Late Kimmeridgian carbonate deposits of NW Switzerland (Swiss Jura): Stratigraphical and palaeogeographical implications in the transition area between the Paris Basin and the Tethys: Sedimentary Geology, 186, 237-263.

Kroeger, K.F., Stinnesbeck, W., 2003, The Minas Viejas Formation (Oxfordian) in the area of Galeana, northeastern Mexico: Significance of syndepositional volcanism and related barite genesis in the Sierra Madre Oriental, in Bartolini, C., Buffler, R.T., Blickwede, J. (eds.), The Circum-Gulf of Mexico and the Caribbean: Hydrocarbon habitats, basin formation, and plate tectonics: Tulsa, Oklahoma, U. S. A., American Association of Petroleum Geologists Memoir 79, 515-528.

Laudon, R.C., 1984, Evaporite diapirs in the La Popa basin, Nuevo León, Mexico: Geological Society of America Bulletin, 95, 1219-1225.

Lauxmann, U., 1991, Revision der oberjurassischen Korallen von Württemberg (SW-Deutschland) exclusive Fungiina: Palaeontographica, Abteilung A, 219, 107-175.

Lawton, T.F., Vega, F.J., Giles, K.A., Rosales-Domínguez, C., 2001, Stratigraphy and Origin of the La Popa Basin, Nuevo León and Coahuila, Mexico, in Bartolini, C., Buffler, R.T., Cantu-Chapa, A. (eds.), The Western Gulf of Mexico Basin: Tectonics, sedimentary basins, and petroleum systems: Tulsa, Oklahoma, U. S. A., American Association of Petroleum Geologists Memoir, 75, 219-240.

López-Ramos, E., 1982, Geología de México (Tomo II): México, D. F., Consejo Nacional de Ciencia y Tecnología, $454 \mathrm{p}$.

Machalski, M., 1998, Oyster life positions and shell beds from the Upper Jurassic of Poland: Acta Geologica Polonica, 43, 609-634.

McBride, E.F., Weidie, A.E., Wolleben, J.A., Laudon, R.C., 1974, Stratigraphy and structure of the Parras and La Popa basins, northeastern Mexico: Geological Society of America Bulletin, 84, 1603-1622.
Meléndez, G., Atrops, F., Ramajo, J., Pérez-Urresti, I., Delvene, G., 2006 Upper Oxfordian to lower Kimmeridgian successions in the NE Iberian Range (E Spain): Some new stratigraphical and palaeontological data: Neues Jahrbuch für Geologie und Palaeontologie, Abhandlungen, 241, 203-224.

Oivanki, S.M., 1974, Paleodepositional environments in the Upper Jurassic Zuloaga Formation (Smackover), northeastern Mexico: Transactions of the Gulf Coast Association of Geological Societies, $24,258-278$

Pindell, J., Kennan, L., 2007, Rift models and the salt-cored marginal wedge in the northern Gulf of Mexico: implications for deep-water Paleogene Wilcox deposition and basin-wide maturation, GCSSEPM Foundation Annual Bob F. Perkins Research Conference Proceedings: Houston, Texas, U. S. A., 27, 146-186.

Pugaczewska, H., 1971, Jurassic Ostreidae of Poland: Acta Palaeontologica Polonica, 16, 195-311.

Riley, T.R., Crame, J.A., Thomson, M.R.A., Cantrill, D.J., 1997, Late Jurassic (Kimmeridgian-Tithonian) macrofossil assemblage from Jason Peninsula, Graham Land: evidence for a significant northward extension of the Latady Formation: Antarctic Science, 9, 434-442.

Rowan, M.G., Lawton, T.F., Giles, K.A., Ratliffe, R.A., 2003, Near-salt deformation in La Popa Basin, Mexico, and the northern Gulf of Mexico: A general model for passive diapirism: American Association of Petroleum Geologists Bulletin, 87, 733-756.

Rubio-Cisneros, I.I., Lawton, T.F., 2011, Detrital zircon U-Pb ages of sandstones in continental red beds at Valle de Huizachal, Tamaulipas, NE Mexico: Record of Early-Middle Jurassic arc volcanism and transition to crustal extension: Geosphere: 7, 159-170.

Salvador, A., 1987, Late Triassic-Jurassic paleogeography and origin of Gulf of Mexico Basin: American Association of Petroleum Geologists Bulletin, 71, 419-451.

Scholz, A., Schweigert, G., Dietl, G., 2008, Bivalves from the Nusplingen Lithographic Limestone (Upper Jurassic, Southern Germany): Paleodiversity, 1, 111-131.

Stern, R.J., Anthony, E., Ren, M., Lock, B.E., Norton, I., Kimura, J.I., Miyazaki, T., Hanyu, T., Qing, C., Hirahara, Y., 2010, Late Jurassic lamprophyres from Louisiana salt domes (abstract), in Geological Society of America North-Central Section 44th Annual and SouthCentral Section 44th Annual Joint Meeting, Branson Missouri: Boulder, Colorado, U. S. A., Geological Society of America, Abstacts with Programs, 42, 39.

Surlyk, F., 1978, Mesozoic Geology and Paleogeography of Hochstetter Forland, East Greenland: Bulletin of the Geological Society of Denmark, 27, 73-87.

Thayer, C.W., 1975, Morphologic adaptations of benthic invertebrates to soft substrata: Journal of Marine Research, 33, 177-189.

Villaseñor, A.B., González-León, C.M., Lawton, T.F., Aberhan, M., 2005, Upper Jurassic ammonites and bivalves from the Cucurpe Formation, Sonora (Mexico): Revista Mexicana de Ciencias Geológicas, $22,65-87$.

Wilson, J.L., 1990, Basement structural controls on Mesozoic carbonate facies in northeastern Mexico-a review, in Tucker, M.E., Wilson, J.L., Crevello, P.D., Sarg, J.R., Read, J.F., (eds.), Carbonate platforms-facies, sequences and evolution: Oxford, U. K., International Association of Sedimentologists Special Publication, 9, 235-255.

Ziegler, B., 1969, Über Exogyra virgula (Laellibranchiata, Oberjura): Eclogae Geologicae Helvetiae, 62, 685-696.

Manuscrito recibido: Septiembre 10, 2009

Manuscrito recibido corregido: Mayo 10, 2009

Manuscrito aceptado: Julio 16, 2010 